deskundige (art. $51 \mathrm{i} \mathrm{t} / \mathrm{m} 51 \mathrm{~m} \mathrm{~Sv}$ ) gelden niet onverkort voor elke persoon die de rechter als deskundige op de zitting hoort. Iemand die enkel als deskundige verklaart of rapporteert over de persoon van de verdachte is natuurlijk een ander type deskundige dan een forensisch deskundige wiens rapport of verklaring bewijswaarde kan hebben. Een reclasseringswerker die een voorlichtingsrapportage uitbrengt over de (persoon van de) verdachte, wordt in beginsel niet als deskundige aangemerkt, maar kan dus wel als deskundige op de zitting worden gehoord zonder dat hij of zij (telkens) in die hoedanigheid wordt benoemd.

\section{NTS 2020/20}

\section{HR 1 oktober 2019, 18/01356, ECLI:NL:HR:} 2019:1456

\begin{abstract}
Opzettelijk handelen in strijd met het in art. 2. A Opiummet gegeven verbod door invoer van ruim $30 \mathrm{~kg}$ ayahuasca-thee bestemd voor kerk. Beroep op recht op vrijheid van godsdienst ex art. 9 EVRM. Was 's Hofs oordeel dat veroordeling voor art. 2 A Opiumpet (invoer harddrugs) en daarmee beperking van recht op vrijheid van godsdienst van verdachte in het onderhavige geval in een democratische samenleving noodzakelijk ter bescherming van volksgezondheid?
\end{abstract}

\section{Aantekening redactie}

De verdachte had vanuit Brazilië zakken met vloeistof met een totaalgewicht van ruim 33 kilogram ingevoerd in Nederland. De vloeistof betrof zogeheten ayahuascathee, een in Brazilië bereide drank die was bestemd voor de kerk Santo Daime in Amsterdam. De verdachte, zelf lid van die kerk en thans in de leiding van de kerk, heeft de thee op verzoek van de toenmalige president van de kerk naar Nederland gebracht, met de bedoeling de thee te doen gebruiken bij de erediensten van het kerkgenootschap, waaraan zij zelf ook deelneemt. Ayahuascathee bevat dimethyltryptamine, verder afgekort en aangeduid als DMT, welk middel staat vermeld op de bij de Opiumwet behorende lijst I. De verdachte had bij binnenkomst in Nederland een brief bij zich van eerdergenoemde president van de kerk van 27 mei 2015, onder meer inhoudende dat de verdachte 'op 5 juni 2015 zal aankomen op Schiphol vanuit Brazilië en als lid van Ceu da Santa Maria vanuit Brazilië Santo Daime meeneemt voor ons kerkgenootschap'. Het invoeren van DMT is verboden in artikel 2 onder A Opiumwet; overtreding van dit verbod is strafbaar gesteld in artikel 10 Opium- wet. De thee wordt gemaakt uit een plant die de psychoactieve stof dimethyltryptamine bevat en een andere plant, die een mono-amine oxidaseremmer (MAO-remmer) bevat. De combinatie van deze twee ingrediënten, DMT en de MAO-remmer, zorgt voor een zeer sterk psychoactief brouwsel met een hevige bewustzijnsveranderende werking. Binnen de Santo Daime-kerk wordt het entheogeen ayahuasca als sacrament beschouwd. Tijdens de diensten wordt in groepsverband ayahuasca gedronken. De vraag die het hof had te beantwoorden was of met de toepassing van voornoemde Opiumwetbepalingen op het handelen van de verdachte een ongerechtvaardigde inbreuk wordt gemaakt op haar recht op vrijheid van godsdienst. De rechtbank had deze vraag nog ontkennend beantwoord. De invoer door de verdachte van de onderhavige ayahuasca-thee ten behoeve van het gecontroleerde en rituele gebruik daarvan binnen de Santo Daime-kerk in Amsterdam, gepaard gaande met toezicht en voorlichting, leverde slechts een zeer gering en dientengevolge aanvaardbaar gevaar voor de gezondheid op. De fout die de rechtbank hier maakte, is dat het gevaar voor de volksgezondheid in dit concrete geval niet relevant is. Zo zit de Opiumwet ook niet in elkaar. Volgens de Opiumwet is de betreffende thee gevaarlijk voor de volksgezondheid. De vraag die dus moet worden beantwoord is of een veroordeling (en daarmee een inbreuk op art. 9 EVRM inzake 'Freedom of thought, conscience and religion'17) in dit specifieke geval in zijn algemeenheid 'was necessary in a democratic society for the protection of public order and health'. In het hier relevante arrest Fränklin-Beentjes en Ceflu-Luz Da Floresta tegen Nederland (nr. 28167/06) overwoog het EHRM het volgende:

'It has long been recognised by the Convention bodies that restrictions on religious practices may be justified for the protection of health; thus it was, for example, that the Commission accepted that the compulsory use of a crash helmet by a motorcyclist, in the interest of road safety, might be held to override the religious duty of a male Sikh believer to wear his turban (see X v. the United Kingdom, no. 7992/77, Commission decision of 12 July 1978, DR 14, p. 234). More recently, the Court accepted that a hospital nurse could be required, in the interest of her own health and safety as well as her patients', not to wear a Christian cross on a chain around her neck while on duty (see Eweida and Others v. the United Kingdom, no. 48420/10, §\$ 98-99, ECHR 2013 (extracts)).

48. In the present case, the Court reaches a similar conclusion. It considers that the respondent party

17. '1. Everyone has the right to freedom of thought, conscience and religion; this right includes freedom to change his religion or belief and freedom, either alone or in community with others and in public or private, to manifest his religion or belief, in worship, teaching, practice and observance.

2. Freedom to manifest one's religion or beliefs shall be subject only to such limitations as are prescribed by law and are necessary in a democratic society in the interests of public safety, for the protection of public order, health or morals, or for the protection of the rights and freedoms of others.' 
was entitled to consider that the prohibition of the possession for use of DMT was necessary in a democratic society for the protection of health, considering its known effects as described above.'

Het verbieden van bepaalde drugs lijkt dus gewoon een legitieme inbreuk op de vrijheid van godsdienst te kunnen maken. De Hoge Raad leidde hieruit af dat voor de beoordeling van de noodzakelijkheid van de inbreuk in een democratische samenleving niet steeds een afweging per situatie is vereist, maar een algemene toetsing volstaat. Het oordeel van het hof dat de toepassing van de betreffende Opiumwetbepalingen en daarmee de beperking van het recht op vrijheid van godsdienst van de verdachte in gevallen als het onderhavige in een democratische samenleving noodzakelijk is ter bescherming van de volksgezondheid, was dan ook niet onbegrijpelijk.

\section{NTS 2020/21}

\section{HR 1 oktober 2019, 17/00380, ECLI:NL:HR:}

2019:1454

Oplichting (meermalen gepleegd) door via 'onzinverhalen' tegenover kmetsbare oudere dame andere personen uit haar kennissenkring te bemegen tot afgeven van geldbedragen t.g.v. verdachte, art. $326 \mathrm{Sr}$

\section{Aantekening redactie}

Voor oplichting ex artikel 326 lid $1 \mathrm{Sr}$ is vereist dat iemand door een oplichtingsmiddel wordt 'bewogen' tot in die bepaling bedoelde handelingen. Niet vereist is dat het oplichtingsmiddel rechtstreeks wordt aangewend jegens degene die wordt bewogen tot desbetreffende handelingen. Oplichting kan ook geschieden door tegenover een (niet-strafbare) tussenpersoon het oplichtingsmiddel an te wenden, mits verdachte daarbij heeft gehandeld met het in artikel $326 \mathrm{Sr}$ bedoelde oogmerk. ${ }^{18}$ Het hof heeft de verdachte wegens 'oplichting, meermalen gepleegd' veroordeeld tot een gevangenisstraf. Het middel bevatte de klacht dat het oordeel van het hof dat de verdachte de in de betreffende personen heeft 'bewogen' tot afgifte van geldbedragen op de wijze zoals bewezen is verklaard, getuigde van een onjuiste rechtsopvatting, althans onbegrijpelijk is dan wel onvoldoende met redenen was omkleed.
Wat was er gebeurd? Verdachte heeft op zeer geraffineerde wijze misbruik gemaakt van een oudere dame, die het goed met hem voorhad. Tegenover haar deed hij zich op allerlei manieren voor als slachtoffer van omstandigheden, dat op korte termijn weer over geld zou kunnen beschikken. Zo heeft verdachte erkend dat hij tegen de oude dame verschillende onzinverhalen heeft verteld. Hij vertelde onder meer dat hij werkzaam was bij de Europese Unie dan wel de NAVO, voor die baan veel moest reizen en hij niet over zijn geld kon beschikken omdat zijn rekening was geblokkeerd dan wel vanwege een registratie bij het BKR. Voorts heeft hij diverse berichten, zoals e-mailberichten van zogenaamde werkgevers en sms-berichten, vals opgemaakt om zijn onzinverhalen kracht bij te zetten. De oude dame had toegang tot deze stukken, en gebruikte de informatie als ze geld vroeg aan anderen ten behoeve van verdachte. De aangevers zijn aanvankelijk steeds benaderd door de oude dame. Zij heeft, nadat haar eigen financiële mogelijkheden ten behoeve van verdachte waren uitgeput, mensen uit haar kennissenkring gevraagd om verdachte financieel te ondersteunen. Op die manier kreeg verdachte toegang tot mensen die hij anders wellicht nooit succesvol had kunnen benaderen: ouderen, die gelet op de (soms al decennia bestaande) vriendschap met de oude dame vol vertrouwen waren. De oude dame vertelde de onzinverhalen die verdachte haar vertelde door aan haar kennissenkring. Vast staat dat al die over verdachte vertelde verhalen 'verzinsels' van verdachte betroffen. Aangevers zijn vervolgens overgegaan tot het geven van geld aan de oude dame ten behoeve van verdachte. De oude dame leidde dit geld telkens door naar verdachte. In totaal zijn er tonnen bij verdachte terechtgekomen en door hem uitgegeven. Toen aangevers, tevergeefs, probeerden hun geld terug te krijgen heeft verdachte ze eindeloos aan het lijntje gehouden en tegen hen gelogen. Door de verdediging werd aangevoerd dat nu er op één situatie na nooit ontmoetingen hebben plaatsgevonden tussen verdachte en deze derden, die derden niet door de verdachte zijn opgelicht. Het hof oordeelde echter dat verdachte op zijn minst de aanmerkelijke kans had aanvaard dat door zijn handelen derden werden bewogen tot het afgeven van geld en dat daarom van oplichting kon worden gesproken. De vraag was dus of van oplichting ook sprake kan zijn als de oplichtingsmiddelen niet rechtstreeks worden aangewend jegens degene die een goed afgeeft, maar door tussenkomst van een derde. Uit eerdere rechtspraak van de Hoge Raad kon reeds worden opgemaakt dat 'indirecte oplichting' wel degelijk mogelijk is, ${ }^{19}$ mits het opzet van de verdachte erop is gericht om van het (niet direct benaderde) slachtoffer de afgifte te verkrijgen. Dat opzet bestaat uit 'oogmerk', wat uiteraard betekent dat voorwaardelijk opzet niet volstaat. $\mathrm{Nu}$ de oude dame in deze zaak niet als medepleger werd aangemerkt en het hof op voorwaardelijk opzet geënte bewoordingen bezigde, was het opzet nog wel een issue. 